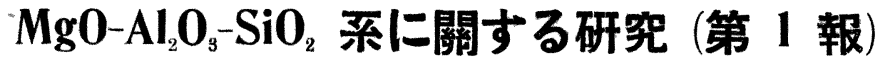

\section{Mg0- $\mathrm{Al}_{2} \mathrm{O}_{3}-\mathrm{SiO}_{2}$ 系調合物の燒締性狀に就て}

\section{伊藤亮}

1. 緒言

近時陶磁器が工業用材料として利用さる」ことが多くなつてから 其原料资源の豐富にして吾國に於て利用容易なるマグネシア質陶嗞 器が各種の方面に活用せらるっに至つた. 就中堇青不磁器は其低膨 脹性を表す默仍ら各種の耐熱性品に應用され又滑不磁器は特殊の電 氣的特性を表す點から近時高周波絕緣物として 現在並に將來に於て 益々活用せられんとしてるるが何れの應用方面に 對してもマグネシ 了質陶磁器素地は其最低燒固點々熔融點々が接近し從て 燒固溫度範 图が狹少なるため不吸水性なる磁器の製造は最も困難とせられ從來 極めて優秀なる特性あるに拘らず製造方法の 困難なるため其發展の 掘延してるることは確實である．本研究はマグネシヤ質陶磁器の基 礎をなす $\mathrm{MgO}-\mathrm{Al}_{2} \mathrm{O}_{3}-\mathrm{SiO}_{2}$ 系配合物の 燒締性狀を系統的に研究し 從來等閑に附せられてるた根本問題を解決せんとして行つたもので ある。

\section{2. 試驗素地の種類}

試驗に供した素地の成分範園は $\mathrm{MgO}=5.4 \sim 68.8 \%, \quad \mathrm{Al}_{2} \mathrm{O}_{3}=0$ 〜 $62.1 \%, \mathrm{SiO}_{2}=7.0 \sim 76.9 \%$ で調合に使用した原料は朝焦慶晌南道河 東郡王宗面正水里產カオリン，滿洲國奉天省大不橋附近蕉 マグネサ

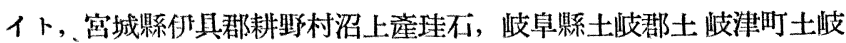
口産蛙目粘土水䇥物，化學用アルミナを使用した各原料の分析表は 次の如くである.

\begin{tabular}{|c|c|c|c|}
\hline & $\mathrm{SiO}_{2}$ & $\mathrm{Al}_{2} \mathrm{O}_{3}$ & $\mathrm{Fe}_{2} \mathrm{O}_{3}$ \\
\hline$\pi$ & 42.50 & 38.26 & 0.34 \\
\hline 蛙目粘土水䬦物 & 16.98 & 37.13 & 0.96 \\
\hline マグネサイト & 0.89 & 0.15 & 0.58 \\
\hline 珪 石 & 98.78 & 0.19 & 0.17 \\
\hline$ア ル$ & 0.21 & 99.23 & 0.09 \\
\hline
\end{tabular}

粘土質原料としてはカオリンを主體とせるも粘力補給の 意味から 全體を通じて $20 \%$ の蛙目粘土水籍物を配合した，アルミナは化學 用アルミナを SK 6a に烺燒したものである.

\begin{tabular}{|c|c|c|c|c|c|c|c|}
\hline \multirow{2}{*}{$\begin{array}{l}\text { 番 } \\
\text { 站 }\end{array}$} & \multicolumn{3}{|c|}{ 主要化學成分 } & \multirow{2}{*}{$\begin{array}{l}\text { 番 } \\
\text { 號 }\end{array}$} & \multicolumn{3}{|c|}{ 主要化學成分 } \\
\hline & $\widetilde{\mathrm{Al}_{2} \mathrm{O}_{3}}$ & $\mathrm{MgO}$ & $\mathrm{SiO}_{2}$ & & $\overparen{\mathrm{Al}_{2} \mathrm{O}_{3}}$ & $\mathrm{MgO}$ & $\mathrm{SiO}$ \\
\hline & 62.1 & 5.5 & 32.4 & $\mathrm{E}_{4}$ & 23.9 & 11.6 & \\
\hline b & 56.2 & 5.4 & 38.4 & $\mathbf{E}_{5}$ & 18.7 & 11.4 & \\
\hline a & 49.7 & 5.7 & 44.6 & $\mathbf{E}_{6}$ & 13.9 & 11.2 & \\
\hline $\mathrm{C}_{1}$ & 43.2 & 5.9 & 50.9 & Gc & 58.2 & 18.2 & \\
\hline $\mathrm{C}_{2}$ & 37.7 & 5.8 & 56.5 & $\mathrm{~Gb}$ & 51.5 & 18.5 & 30. \\
\hline $\mathrm{C}_{3}$ & 325 & 5.7 & 61.7 & $\mathrm{Ga}$ & 44.3 & 18.9 & 36. \\
\hline $\mathrm{C}_{4}$ & 27.6 & 5.5 & 67.0 & $\mathrm{G}_{1}$ & 37.3 & 19.0 & 43 \\
\hline $\mathrm{C}_{5}$ & 22.4 & 5.5 & 72.1 & $\dot{\mathrm{G}}_{2}$ & 31.2 & 18.7 & 50 \\
\hline $\mathrm{C}_{6}$ & 17.7 & 5.4 & 76.9 & $\mathrm{G}_{3}$ & 25.4 & 18.5 & 56. \\
\hline Ec & 60.3 & 11.5 & 28.3 & $\mathrm{G}_{4}$ & $20.4^{*}$ & 17.9 & 61. \\
\hline $\mathrm{Eb}$ & 53.9 & 11.7 & 34.4 & $\mathrm{G}_{6}$ & 14.9 & 17.8 & 67. \\
\hline Ea & 47.0 & 12.0 & 41.0 & $\mathrm{G}_{6}$ & 9.5 & 17.1 & 73 \\
\hline $\mathbf{L}_{1}$ & 40.1 & 12.2 & 47.7 & Ic & 55.8 & 25.5 & 18.7 \\
\hline & 34.6 & 12.0 & 53.4 & Ib & 48.7 & 26.0 & 25. \\
\hline
\end{tabular}

\begin{tabular}{|c|c|c|c|c|c|c|c|}
\hline $\mathbf{E}_{3}$ & 29.2 & 11.8 & 59.0 & Ia & 41.2 & 26.5 & 32.3 \\
\hline$I_{1}$ & 33.5 & 27.0 & 39.5 & $\mathrm{Ma}$ & 33.8 & 44.5 & 21.7 \\
\hline $\mathbf{I}_{2}$ & 27.3 & 26.6 & 46.1 & $\mathbf{M}_{1}$ & 25.1 & 45.5 & 29.5 \\
\hline$I_{3}$ & 21.5 & 26.0 & 52.5 & $\mathrm{M}_{2}$ & 18.4 & 44.5 & 37.2 \\
\hline$I_{4}$ & 15.8 & 25.6 & 58.6 & $\mathbf{M}_{3}$ & 11.9 & 43.5 & 44.6 \\
\hline$I_{5}$ & 10.0 & 24.3 & 65.7 & $\mathrm{M}_{4}$ & 5.9 & 42.6 & 51.5 \\
\hline $\mathrm{Kc}$ & 53.3 & 33.6 & 13.1 & $\mathrm{M}_{5}$ & - & 41.8 & 58.2 \\
\hline $\mathrm{Kb}$ & 45.7 & 34.2 & 20.1 & $\mathrm{Ob}$ & 38.6 & 53.9 & 7.5 \\
\hline $\mathbf{K a}$ & 37.7 & 35.0 & 27.3 & $\mathrm{Oa}$ & 29.4 & 55.2 & 15.4 \\
\hline $\mathbf{K}_{1}$ & 29.5 & 35.8 & 34.7 & $\mathrm{O}_{1}$ & 19.8 & 56.1 & 23.5 \\
\hline $\mathbf{K}_{2}$ & 23.1 & 35.0 & 41.9 & $\mathrm{C}_{2}$ & 13.1 & 55.0 & 31.8 \\
\hline $\mathbf{K}_{3}$ & 17.0 & 34.2 & 48.8 & $\mathrm{O}_{3}$ & 6.4 & 53.9 & 39.7 \\
\hline $\mathbf{K}_{4}$ & 10.8 & 32.4 & 56.8 & $\mathrm{O}_{4}$ & - & 52.8 & 47.2 \\
\hline $\mathbf{K}_{5}$ & 5.5 & 33.0 & 61.5 & $\mathrm{Qa}$ & 24.5 & 67.4 & 8.1 \\
\hline $\mathbf{K}_{6}$ & -- & 32.5 & 67.5 & $\mathrm{Q}_{\mathbf{l}}$ & 14.3 & 68.8 & 16.8 \\
\hline Mc & 50.3 & 42.7 & 7.0 & $\mathbf{Q}_{2}$ & 7.0 & 67.2 & 25.8 \\
\hline $\mathrm{Mb}$ & 42.3 & 43.6 & 14.1 & $\mathbf{Q}_{3}$ & -. & 65.6 & 34,4 \\
\hline
\end{tabular}

以上各調合物を三角圖表上に示すと第 1 圖の如くになる.

\section{3. 實 驗 方 法}

各原料は預め徽粉碎し各調合比により所定素地を配合し $2 \mathrm{~kg}$ ポ ットミルにて 30 時間粉倅混合せる後取出し脫水して坯土とし之に 依り大形ゼーゲル錐（高さ約 $61 \mathrm{~mm}$. 底渗の長さ約 $16 \mathrm{~mm}$ ) 及小形 ゼーゲル錐（高さ約 $27 \mathrm{~mm}$, 底邊の長さ約 $7 \mathrm{~mm}$ ) と同形同大の 試驗體を金型を用ひて成形した。燒成哭は可及的實際の燒成に近 似せしむるため $58 \times 43 \times 60 \mathrm{~cm}$ の石炭燃燒式試驗筧を使用し最低

\begin{tabular}{rrrrrr}
$\mathrm{CaO}$ & $\mathrm{MgO}$ & $\mathrm{K}_{2} \mathrm{O}$ & $\mathrm{Na}_{2} \mathrm{O}$ & lg-loss & \multicolumn{1}{c}{ 計 } \\
0.98 & 0.45 & 0.55 & 1.27 & 15.28 & 99.63 \\
0.35 & 0.22 & 0.26 & 0.21 & 13.91 & 100.02 \\
0.76 & 47.62 & - & - & 49.23 & 99.23 \\
0.18 & 0.27 & $\underbrace{0.11}_{0.10}$ & 0.13 & 0.17 & 100.00 \\
0.08 & 0.02 & & 0.28 & 100.00
\end{tabular}

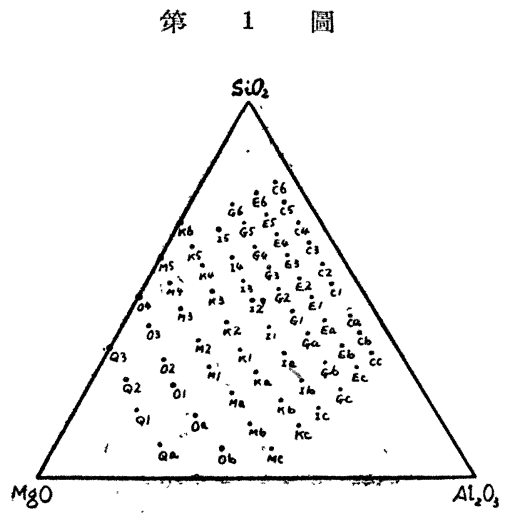

火度を $\mathrm{MgO}-\mathrm{Al}_{2} \mathrm{O}_{3}-\mathrm{SiO}_{2}$ の共融點の溫度に近き $\mathrm{SK} 12$ と定め之以 上をゼーゲル錐各番號每に火度を上昇せしめつ」反覆して憢成を行 つた. 燒成時間は總じて 10〜15 時間で所定のゼーゲル錐の熔倒し た時に燒成を止め其儘放冷した. 然し調合素地中には相當高火度に 達するも容易に熔骶しないものもあるので石炭然燒試驗黨はゼーゲ 
ル錐 15 番を以て中此し之以上 $\mathrm{SK26}\left(1580^{\circ} \mathrm{C}\right)$ 迄は瓦斯試驗爐を 使用し更に SK27 $\left(1610^{\circ} \mathrm{C}\right)$ 以上の燒成には耐火度測定用酸素アセ チレン㠠（東工試報告第 30 回第 5 號參照）を使用した、試驗體は 石炭燃焅筀及瓦斯盧の場合は何れも大型を使用し酸素アセチレン爐 の場合には小型を用ひた.

各溫度に燒成した試驗體は其燒火性狀を檢する鹪吸水率を測定し 同時に最低磁器化點及耐火度を測定した.

\section{4. 實 驗 結 果}

\section{(1) 吸水率}

各試驗體に付き測定した吸水率 (\%) の測定結果は第 3 表の如く である.

表中變形々印せるは軟化變形するも猫原形を認め得るもの, 熔融 と印せるは熔融して原形を認め得ざる狀態に達したものである.

（2）耐火度最低燒固點及燒固溫度範園

上記試驗結果より各素地の耐火度最低焅固點及び燒固溫度範圍を 揭ぐれば第っ表の如くになる。

\begin{tabular}{|c|c|c|c|}
\hline $\begin{array}{l}\text { 番 } \\
\text { 號 }\end{array}$ & $\begin{array}{l}\text { 最低燒闻點 } \\
\text { (SK) }\end{array}$ & $\begin{array}{c}\text { 耐火度 } \\
\text { (SK) }\end{array}$ & $\begin{array}{c}\text { 燒固溫度範圍 } \\
\text { (SK) }\end{array}$ \\
\hline $\mathrm{Cc}$ & 19 & 33 & 9 \\
\hline $\mathrm{Cb}$ & 26 & 31 & 5 \\
\hline $\mathrm{Cc}$ & 17 & 31 & 9 \\
\hline $\mathrm{C}_{1}$ & 14 & 29 & 10 \\
\hline $\mathbf{C}_{2}$ & 14 & 28 & 9 \\
\hline $\mathbf{C}_{3}$ & 16 & 19 & 3 \\
\hline $\mathrm{C}_{4}$ & 16 & 17 & 1 \\
\hline $\mathrm{C}_{5}$ & 16 & 17 & 1 \\
\hline $\mathrm{C}_{\mathbf{B}}$ & 17 & 17 & 0 \\
\hline Ec & 20 & 27 & 2 \\
\hline $\mathrm{Eb}$ & 20 & 27 & 2 \\
\hline Ea & 17 & 27 & 5 \\
\hline $\mathrm{E}_{1}$ & 15 & 18 & 3 \\
\hline $\mathbf{E}_{2}$ & 17 & 17 & 0 \\
\hline $\mathbf{E}_{3}$ & 16 & 17 & 1 \\
\hline $\mathbf{E}_{4}$ & 14 & 14 & 0 \\
\hline $\mathbf{E}_{5}$ & 16 & 16 & 0 \\
\hline $\mathrm{F}_{6}$ & 17 & 17 & 0 \\
\hline $\mathrm{Gc}$ & 17 & 18 & 1 \\
\hline $\mathrm{Gb}$ & 17 & 17 & 0 \\
\hline $\mathrm{Ga}$ & 17 & 17 & 0 \\
\hline $\mathrm{G}_{1}$ & 16 & 16 & 0 \\
\hline $\mathrm{G}_{2}$ & 16 & 16 & 0 \\
\hline $\mathbf{G}_{3}$ & 14 & 14 & 0 \\
\hline $\mathrm{G}_{4}$ & 14 & 14 & 0 \\
\hline $\mathrm{G}_{5}$ & $1 b$ & 15 & 0 \\
\hline$G_{0}$ & 18 & 19 & 1 \\
\hline
\end{tabular}

\begin{tabular}{lllc}
$\mathrm{Ic}$ & 17 & 20 & 3 \\
$\mathrm{Ib}$ & 15 & 17 & 2 \\
$\mathrm{Ia}$ & 14 & 14 & 0 \\
$\mathrm{I}_{1}$ & 14 & 14 & 0 \\
$\mathrm{I}_{2}$ & 14 & 14 & 0 \\
$\mathrm{I}_{3}$ & 14 & 14 & 0 \\
$\mathrm{I}_{4}$ & 14 & 14 & 0 \\
$\mathrm{I}_{5}$ & 14 & 16 & 2 \\
$\mathrm{Kc}$ & 29 & 40 以上 & 12 以上 \\
$\mathrm{Kb}$ & 19 & 28 & 4 \\
$\mathrm{Ka}_{\mathrm{a}}$ & 14 & 18 & 4 \\
$\mathrm{~K}_{1}$ & 14 & 16 & 2 \\
$\mathrm{~K}_{2}$ & 14 & 14 & 0 \\
$\mathrm{~K}_{3}$ & 14 & 14 & 0 \\
$\mathrm{~K}_{4}$ & 16 & 16 & 0 \\
$\mathrm{~K}_{5}$ & 17 & 17 & 0 \\
$\mathrm{~K}_{6}$ & 16 & 16 & 0 \\
$\mathrm{Mc}_{\mathrm{M}}$ & 36 & 40 以上 & 5 以上 \\
$\mathrm{Mb}_{\mathrm{Ma}}$ & 33 & 33 & 0 \\
$\mathrm{M}_{1}$ & 33 & 33 & 0 \\
$\mathrm{M}_{2}$ & 14 & 29 & 10 \\
$\mathrm{M}_{3}$ & 14 & 16 & 2 \\
$\mathrm{M}_{4}$ & 14 & 14 & 0 \\
$\mathrm{M}_{5}$ & 16 & 18 & 2 \\
$\mathrm{Ob}$ & 17 & 17 & 0 \\
$\mathrm{Oa}$ & 33 & 40 以上 & 8 以上 \\
$\mathrm{O}_{1}$ & 30 & 33 & 3 \\
$\mathrm{O}_{2}$ & 26 & 32 & 6 \\
$\mathrm{O}_{3}$ & 15 & 32 & 12 \\
$\mathrm{O}_{4}$ & 18 & 28 & 5 \\
$\mathrm{Qa}_{\mathrm{Q}_{1}}$ & 19 & 19 & 0 \\
$\mathrm{Q}_{2}$ & 33 & 33 & 0 \\
$\mathrm{Q}_{3}$ & 20 & 32 & 7 \\
& 29 & 35 & 6 \\
& 36 & 36 & 0 \\
\hline & & &
\end{tabular}

上表中の最低燒固點は各素地が同火度に於て最初に磁器狀を呈す る點で本試驗に於ては便宜上吸水致が $1 \%$ 以下に低下した點を探用 した. 憢固溫度範圍は此溫度範園內に於ては各素地共磁器狀を呈す る燒成溫度の範圍で燒固溫度範園の長いもの程磁器の燒成は容易で あることは云ふ迄むない。

\section{5. 成 績 の 綜 合}

以上實驗結果を $\mathrm{MgO}-\mathrm{Al}_{2} \mathrm{O}_{3}-\mathrm{SiO}_{2}$ 三成分圖表上に示せば第 2 圖 (最低燒周點) 第 3 圖 (耐火度), 第 4 圖 (燒周溫度範冏) の如< になる。

本試驗の耐火度曲線は G. A. Rankin 及 H. E. Merwin 兩氏の 實驗 (Amer. Jour. Sci. (4), 45, (1918)), による $\mathrm{MgO}-\mathrm{Al}_{2} \mathrm{O}_{3}-\mathrm{SiO}$
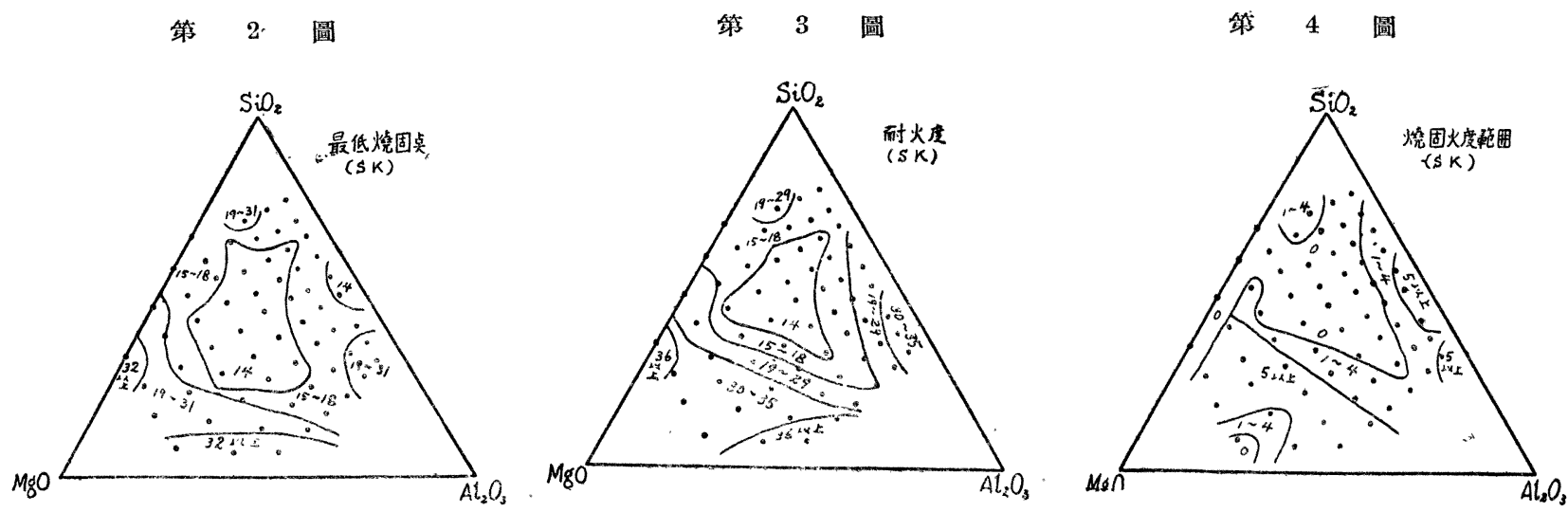
$\begin{array}{lllllllllllllllllllllllllllllllllll}8 & 1 & 1 & 1 & 1 & 1 & 1 & 1 & 1 & 1 & 1 & 1 & 1 & 1 & 1 & 1 & 1 & 1 & 1 & 1 & 1 & 1 & 1 & 1 & 1 & 1 & 1 & 1 & 1 & 1 & 1 & 1 & 1 & 1 & 1\end{array}$

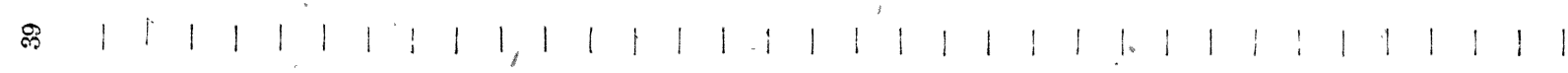

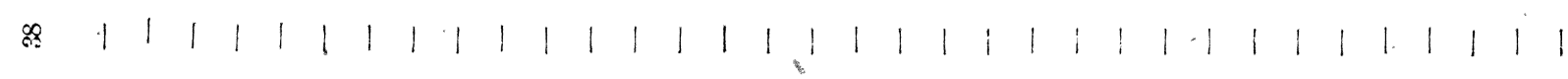

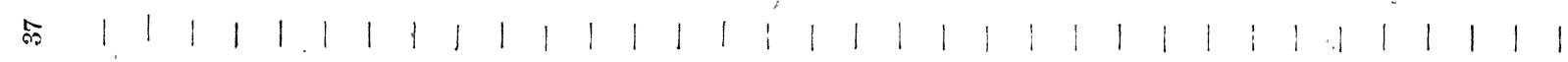

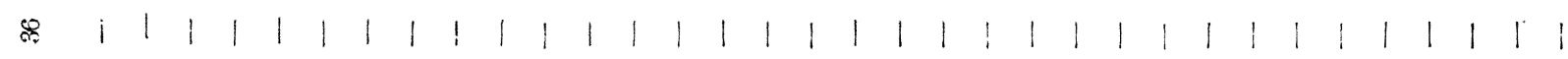

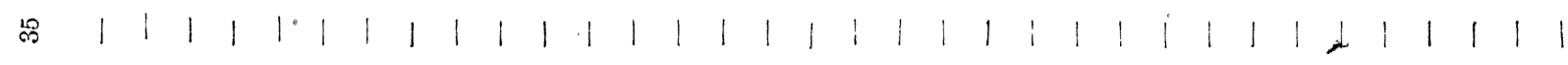

$\begin{array}{lllllllllllllllllllllllllllllllllll}0 & 1 & 1 & 1 & 1 & 1 & 1 & 1 & 1 & 1 & 1 & 1 & 1 & 1 & 1 & 1 & 1 & 1 & 1 & 1 & 1 & 1 & 1 & 1 & 1 & 1 & 1 & 1 & 1 & 1 & 1 & 1 & 1 & 1 & 1\end{array}$

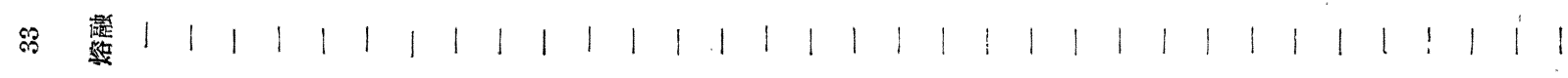

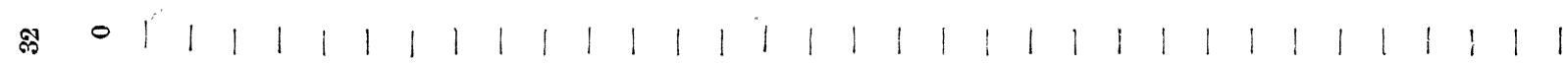

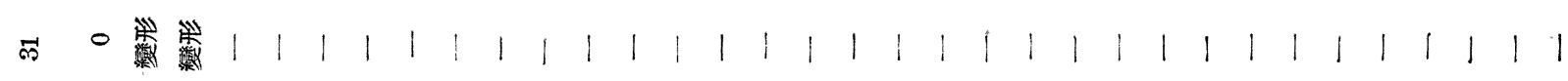

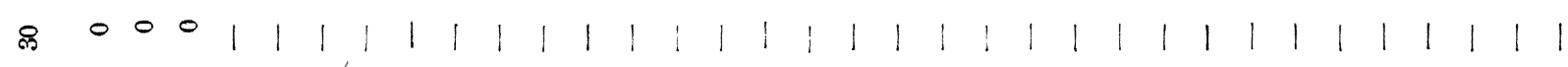

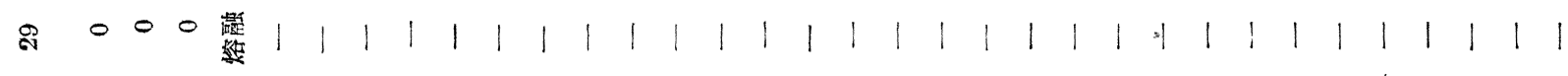

册

๓ ลิ

虽

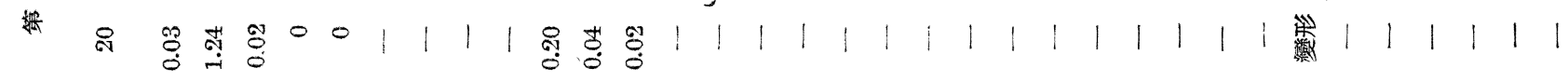

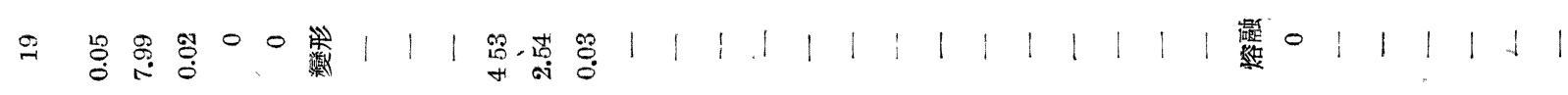

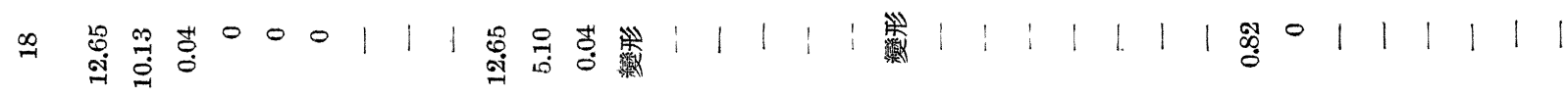

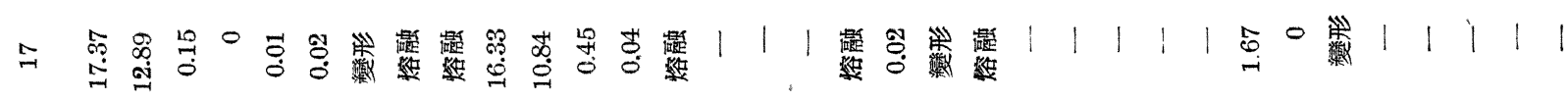

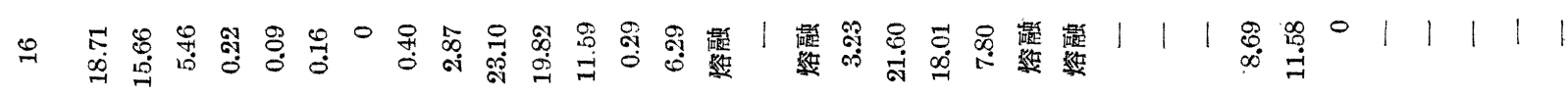

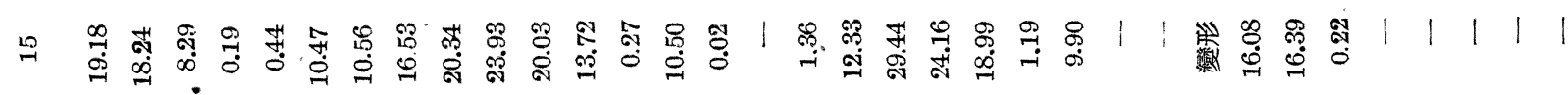

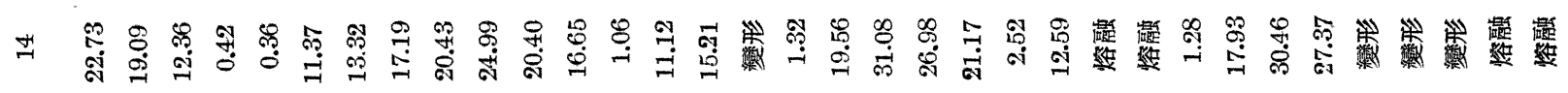

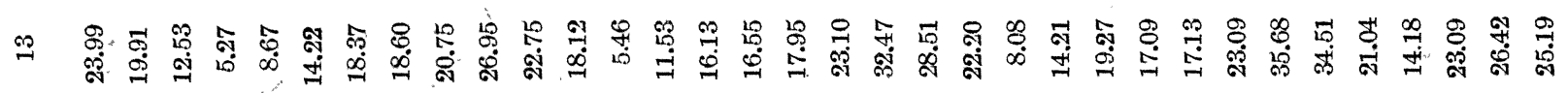

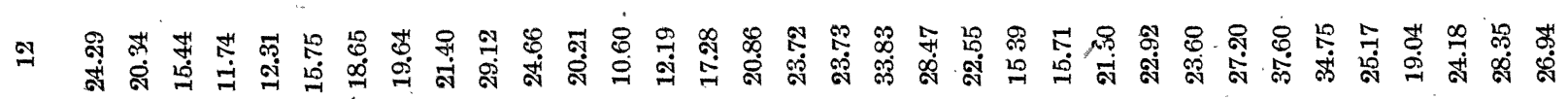
幽/ 


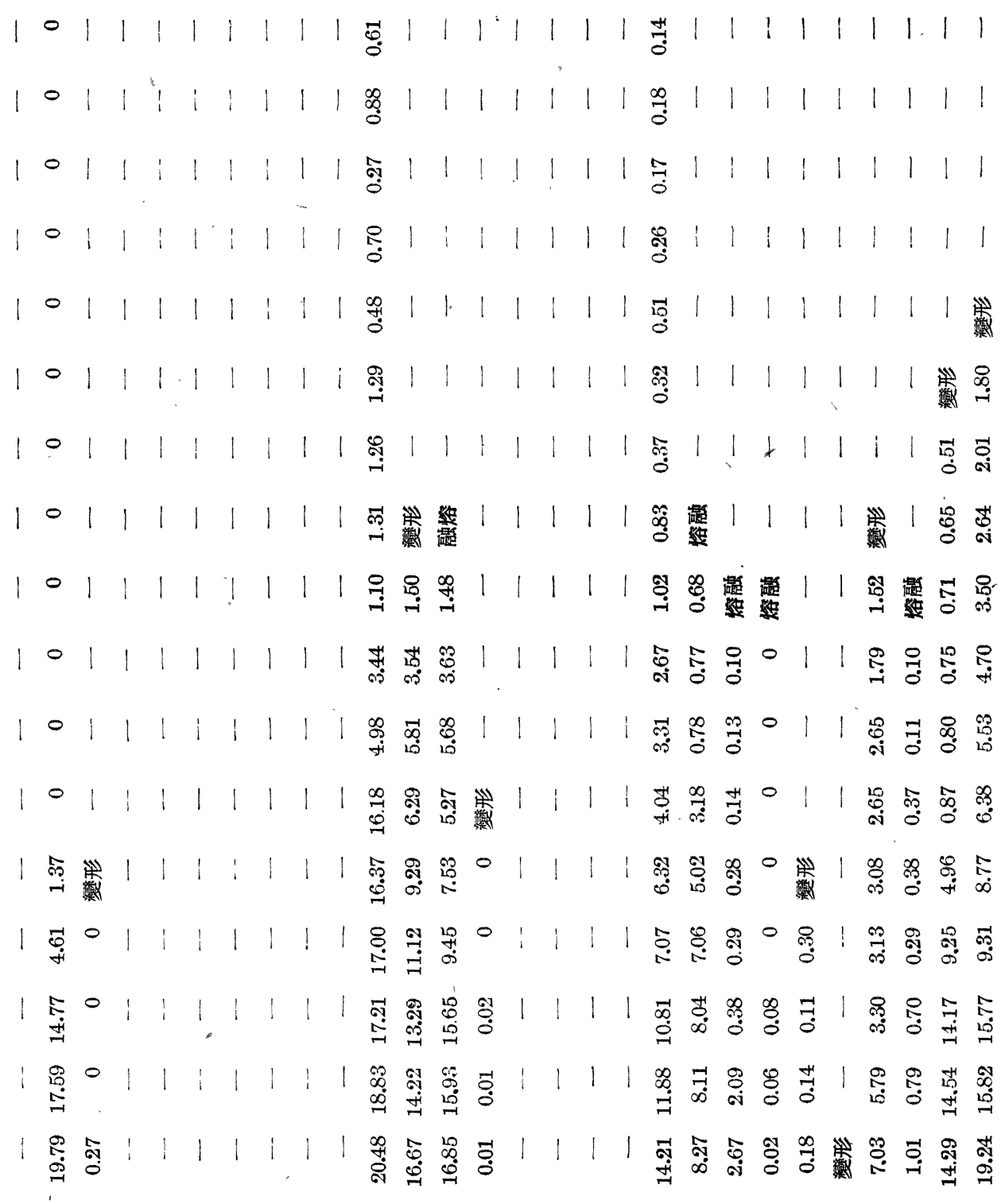

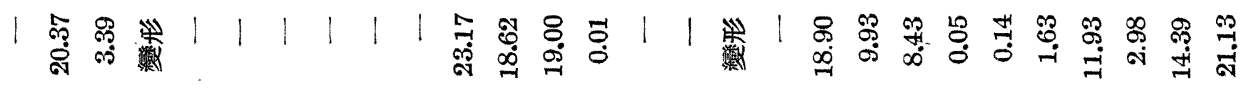

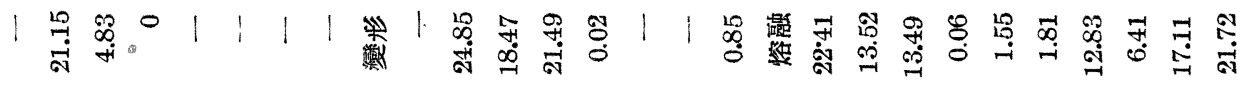

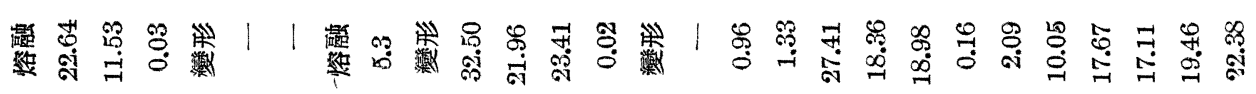

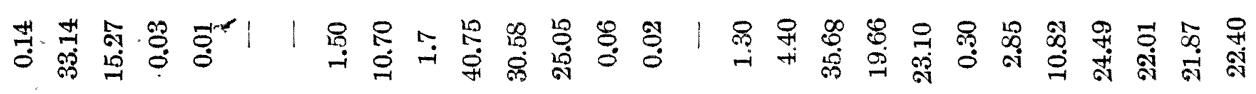

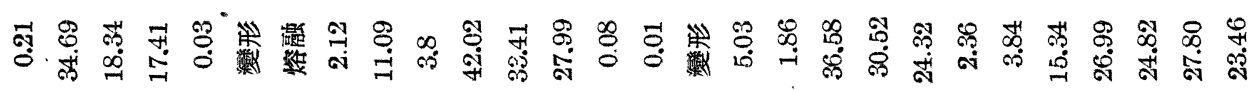

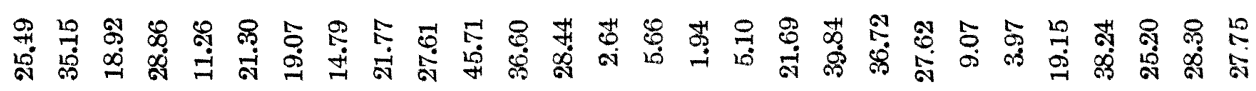

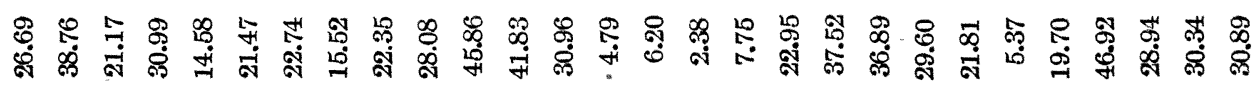
นำ 
の平衡圖とは必ずしも一致はしないが大體の傾向は合致してるる. 郎ち耐火度の最も低い部分は SK14 で本圖の中央部の不規則な四邊 形狀の曲線にて示される. 但し本實驗では Rankin 及 Merwin 兩 氏の示した最低共融點 $1345^{\circ} \mathrm{C}$ 及 $1360^{\circ} \mathrm{C}$ の兩點を明かに示さない 之は恐らく其共融點の成分に合致した配合物が無かつたものであら 5. 更に高耐火度曲線が同四邊形曲線の周圍に撗大してるる狀態は 前述兩氏の平衡圖に非常に近似してるる.

第 2 圖の最低燒固點の曲線は勿論利火度曲線に影響があり低耐火 度のものは最低燒固點も低火度であるが唯本試驗素地中 最低燒固點 を示す SK14 の範嘻は耐火度の場合に比し相當撗大し特に $\mathrm{MgO}$ 及 $\mathrm{Al}_{2} \mathrm{O}_{3}$ の增大寸る方向郎ち尖晶不圈に掳張してるる. 其他利火度高 き部分は一般に最低燒固點も漸次上昇してるる. 第 4 圖の燒固溫度 範圍曲線を見るに磁器化溫度範園最も狹少な部分郎ち 燒固溫度範園 SK 1 以下のものは耐火度曲線にて最低耐火度を示した中央部師ち 堇青不, 頑火石, 苦土橄憯石圈の一部であるが更に $\mathrm{SiO}_{2} \sim \mathrm{MgO}$ 二成 分系に屬する部分郎ち $\mathrm{K}_{6}, \mathrm{M}_{5}, \mathrm{O}_{4}, \mathrm{Q}_{3}$ 等は何れも最狹の 燒固溫度範 圍を示し之等は何れも事實上不吸水性磁器の製造は極めて困難なる のである. 次に $\mathrm{MgO}$ 及 $\mathrm{Al}_{2} \mathrm{O}_{3}$ の增加郎ち尖晶不圈の方向に對し ては燒固溫度範圍は相當撗大され SK5 以上 10 內外の廣い燒固溫 度範圍を示す. 又 $\mathrm{SiO}_{2}$ 及 $\mathrm{Al}_{2} \mathrm{O}_{3}$ の增加郎ちムライト圈及鋼玉石 圈の方向に對しても燒固溫度範四は相當搌大される 事は第 4 圖曲 線より明かである.クリストバライト圈の方向に對しては $\mathrm{I}_{5}{ }^{\prime} \mathrm{G}_{6}$ の 如く燒固溫度範園の撗大は認められるが前述した他の場合に比し本 試驗に於ては著しい影響は認められない，唒 $\mathrm{SiO}_{2} \sim \mathrm{MgO}$ 二成分系 に屬する如き素地の燒固溫度範圍の狹少なることは恐らく其構造上
二次的生成鑛物が單一狀に生成さるるに起因するものと考へられ る.

何れにしても $\mathrm{MgO}-\mathrm{Al}_{2} \mathrm{O}_{3}-\mathrm{SiO}_{2}$ の如き系統の配合物に於ては其 燒成物は殆んど二次的生成鑛物の單一又は複雜なる結晶體の 集合で 硝子質は比較的存在する割合が少いから之等の素地の燒固溫度範圍 は之等素地の鑛物的構造に吝配されることが著しいものと思考され る.

特に著しい例は本試驗素地中燒固溫度範圍 0 なる部分郎ち堇青 不を主とするものに在つては熔融直前迄相當の吸水性を保有するが 之が熔融變形した後の試驗體を見るに變形狀態の儘にて唒吸水性を 有してるるものもある. 之は勿論熔融後に於て素地の二次的生成鑛 物のため失透し結晶間临に吸水するものと思はれる. 此種の 素地が 熔融直前迄相當の吸水率を有寸ることも素地の燒成中に於て素地中 に發達寸る二次的鑛物結晶の生成に起因寸るものなることは同樣に 想像され得る. 從て此の如き調合物では單に燒成中に生成すると考 へられる硝子質の存在は素地の燒固に關しては著しい效果は期待出 來ない事になる．然し上述の樣に失透性の著しい部分は主として堇 靑石の發達するもので他の二次生成鑛物の生成するものはそれ 程著 しい失透を起さない，特に第 4 圖に於て苦土檄欖石と尖晶石を結 合する直線を中心として䒧固溫度範園は相當撗大される倾向のある ことは注目すべき點である。

終りに臨み本賽驗に從事されを富瀨信明及濱嶋政治兩氏の勞を謝す ると共に本研究費の一部を補助せられたる技術院の御捘助に對し謝意 を表与.（東京工業試驗所第一部第三課研究室）(昭 19.4.7 受付)

雜報

土と石灰の瓦 住宅營團では瓦の不足を打開するため土と石灰及 び石炭殸を用ひて試作研究してるたが，最近十分使用に耐へる製品 を完成するに至つた．セメント瓦よりも弱?，吸水量も多いが，少 量の石灰以外には然料を使は奴點が注目に價する，石炭款を混ぜる のは目方を輕くし且つ質を粗くして割れを防ぐためで，原土には叮 き土に使ふ花南岩の沈積砂を用ひる。

製法は鐵型に入れて 3000 ポンドの麽力をかけ型から外してぬれ 菰で包んで日蔭で 2,3 日養生し，硬化してから更に約 3 週問蔭 干しする．製品は古くなつて枯れてくる程强くなる．營團ではま う水麼器を 3 臺買大れて製作準備中であるが， 1 臺當り月產は 500 枚程度である。

焼塊确火龽瓦 セメント精製上不可缺なる耐火煉瓦は入手難なの で，セメント統制會では之が自給自足を圖るべく，英下各工場に於 いて燒塊（クリンカー）に依る代用品を製作使用してるるが，その 技術は各工場區々であり，中には使用に耐へぬるのもあるので，統 制會技術部では優秀な製造及び使用技術を有する暂城せメント工場
に傘下工場の關係技術者を招き 之が技術の交流公開並に研究會を開 催した, 要項次の如し.

（1）工場作業場見學及び研究

(2) 研究會 $=$ 研究懇談事項

(1) 燒塊煉瓦製作關保

(1)使用寸る燒塊の品質容量其他 (2)使用燒螝粒の大さ及び其範 圍 (3)セメント其他配合材の配合割合 (4)混合水量 (5混合方 法 6燒塊煉瓦の大さ及び耐火熑瓦と比較し其大小得失等 (7) 燒塊煉瓦の型枠(材質及び構造）(8)燒塊煉瓦の詰め方及び成形 （填充, 搗固め, 脫型等) (9)養生方法及び期間等 (101 人 1 日 の作業能力及び燒塊煉瓦の單價 (11)其他製作上に於し、て注意寸 べき事項氣付の點

（口）燒塊煉瓦使用狀況關係

(1)燒塊煤瓦製造後使用迄の期間（養生後乾燥其他使用迄の期間 等) (2)使用個所(燒成帶㶯) 燒帶又は全部等其使用範圍 (3)煉 瓦の卷方, 燒塊煉瓦の夕使用するや, 而火煉瓦と混用なるや, 混用の場合は耐火煤瓦と段置き又は 2 段置き又は 3 段置き等交 互使用なるや等及び其の際注意すべき事項 (4)使用成績 (5)燒 成作業上注意すべき諸事項 (6)其他使用上に於いて注意すべき 事項等氣付の點 